\title{
Beberapa Aspek Pengelolaan OPT Ramah Lingkungan, Suatu Upaya Mendukung Pertanian Berkelanjutan
}

\author{
Various Aspects of Eco-Friendly Plant Pest Organism Management, An Effort to Support \\ Sustainable Agriculture
}

Gayuh Prasetyo Budi

Fakultas Pertanian dan Perikanan, Universitas Muhammadiyah Purwokerto

\section{PENDAHULUAN}

Di dalam UU RI No.22 Th. 2019 telah diputuskan bahwa yang dimaksud Sistem Budi Daya Pertanian Berkelanjutan adalah pengelolaan sumber daya alam hayati dalam memproduksi komoditas pertanian guna memenuhi kebutuhan manusia secara lebih baik dan berkesinambungan dengan menjaga kelestarian lingkungan hidup. Tujuan Sistem Budi Daya Pertanian Berkelanjutan adalah untuk: a. Meningkatkan dan memperluas penganekaragaman hasil pertanian, guna memenuhi kebutuhan pangan, sandang, papan, kesehatan, industri dalam negeri, dan memperbesar ekspor; b. Meningkatkan pendapatan dan taraf hidup Petani; dan c. Mendorong perluasan dan pemerataan kesempatan berusaha dan kesempatan kerja.

Dapat diartikan pertanian berkelanjutan merupakan gerakan pertanian berprinsip ekologi yang mempunyai fungsi secara jangka panjang dan berkesinambungan: memenuhi kebutuhan pangan dan serat manusia, meningkatkan kualitas lingkungan dan sumber daya alam, menggunakan sumber daya alam tidak terbarukan secara sangat efisien, menggunakan sumber daya yang tersedia di lahan pertanian secara terintegrasi dan memanfaatkan pengendalian dan siklus biologis jika memungkinkan, meningkatkan kualitas hidup petani dan masyarakat secara keseluruhan. Pertanian berkelanjutan sebagai suatu usaha budidaya tanaman yang secara berkesinambungan bisa memenuhi kebutuhan pangan dan gizi, kesehatan serta kesejahteraan manusia dengan menghindari semaksimal mungkin efek negatif pada lingkungan yang mungkin timbul.

\section{Ekosistem Alamiah dan Ekosistem Pertanian.}

Pada awal manusia mulai mengusahakan pertanian untuk pemenuhan kebutuhan hidup, yang terjadi adalah perubahan ekosistem dari ekosistem alamiah menjadi ekosistem pertanian. Perubahan yang terjadi adalah heterogenitas populasi tanaman yang semula tinggi berubah menjadi rendah dan berdampak pada heterogenitas hewan juga semakin berkurang. Adanya pengolahan tanah berlebih dan penggunaan pupuk serta pestisida kimia sintetik yang intensif pada ekosistem pertanian menyebabkan terjadi perubahan: tanah mudah erosi, tanah lebih masam atau lebih basa, populasi dan aktivitas organisme berguna di dalam tanah berkurang, organisme berguna di atas permukaan tanah (penyerbuk, predator, parasitoid) berkurang, kandungan air tanah cepat hilang dan kesuburan tanah menurun akibat nutrisi yang semakin lama semakin berkurang. Penggunaan pestisida dengan intensitas tinggi dan tidak bijaksana pada ekosistem pertanian berpengaruh besar menjadikan organisme pengganggu tanaman meningkat jenis dan jumlahnya.

Perubahan keseimbangan pada ekosistem pertanian menyebabkan lonjakan populasi organisme pengganggu tanaman. Hama dan patogen penyebab penyakit pada tanaman yang meningkat secara drastis menjadi faktor penghambat yang penting dalam usaha meningkatkan kuantitas dan kualitas hasil tanaman. Ekosistem pertanian menjadi suatu area yang sangat cocok bagi perkembangbiakan organisme pengganggu tanaman, hal ini antara lain karena (Untung, 2006):

1. Penanaman monokultur dengan varietas tanaman yang sama sepanjang waktu dan tempat

2. Penanaman varietas tanaman yang unggul produksi tetapi peka organisme pengganggu

3. Penanaman jenis tanaman baru di suatu daerah sehingga belum ada musuh alami di lokasi baru

4. Penggunaan masukan produksi yang berlebihan seperti pestisida kimia, pupuk buatan, hormon tumbuh dan lainnya.

5. Penggunaan pestisida kimia berspektrum lebar yang dilakukan secara tidak bijaksana, terus-menerus dan berlebihan. Pestisida menyebabkan resistensi dan membunuh musuh alami sehingga terjadi resurjensi. 
Masalah organisme pengganggu tanaman dan efek negatif pada lingkungan serta gangguan kesehatan manusia yang terjadi akan terus ada dikarenakan aktivitas manusia.

\section{Efek Negatif Pestisida Kimia Sintetik}

Di bidang budidaya pertanian, pestisida merupakan bagian yang tidak terpisahkan. Petani khususnya tanaman hortikultura sayuran dan buah-buahan sebagian besar menggunakan pestisida secara berlebihan karena kekhawatiran resiko gagal panen (Amilia $d k k$., 2016). Terlebih sejak pestisida dikenal efektif dalam mengendalikan organisme pengganggu tanaman dan banyak anggapan masyarakat bahwa tanpa menggunakan pestisida tidak mendapatkan hasil panen maka pestisida menjadi primadona. Di Sulawesi Utara hampir semua petani di tahun 1990 sudah menggunakan pestisida kimia untuk mengendalikan hama dan penyakit pada tanamannya (Sembel dalam Singkoh dan Katili, 2019). Menurut Hasyim dkk., (2015), petani di sentra produksi cabai telah menggunakan lebih dari 60 jenis pestisida dengan frekuensi penggunaan 2-3 hari sekali per minggu dan menghabiskan biaya $35-50 \%$ dari total biaya produksi.

Ratna $d k k$., (2009) melaporkan di Indonesia pernah terjadi resurjensi (letusan) wereng coklat $N$. lugens pada tanaman padi beberapa kali kejadian pada tahun 1978-1979 (750.000 ha), tahun 1997-1998 (100.000 ha), tahun 2005 (60.000 ha) dan 2006 (30.000 ha). Hal ini memberikan gambaran efek negatif akibat penggunaan insektisida yang berlebihan untuk mengendalikan $N$. lugens pada tanaman padi. Pestisida berspektrum lebar sering menyebabkan resistensi, resurjensi dan ledakan hama kedua. Selain itu efek negatif pestisida juga dapat berupa: matinya organisme berguna, pencemaran lingkungan, pencemaran pada tanaman atau hasil panen serta gangguan kesehatan manusia.

\section{Resurjensi}

Resurjensi adalah timbulnya ledakan populasi hama tertentu setelah pengaplikasian pestisida. Resurjensi bisa terjadi karena: terbunuhnya musuh alami, migrasi massal, peningkatan sistem reproduksi serangga, peningkatan laju konsumsi makanan dari suatu hama karena meningkatnya nutrisi tanaman inang, semakin pendek lama stadium nimfa dan semakin panjang lama stadium imago sehingga menyebabkan periode oviposisi lebih lama (Ratna $d k k, 2009)$.

\section{Resistensi}

Resistensi pestisida pada organisme pengganggu tanaman berkembang setelah adanya proses seleksi yang berlangsung selama banyak generasi. Resistensi merupakan suatu fenomena evolusi yang diakibatkan oleh seleksi pada organisme pengganggu tanaman, bisa disebabkan perlakuan pestisida secara terus menerus. Salah satu faktor yang mempengaruhi laju perkembangan resistensi serangga hama akibat insektisida adalah tingkat tekanan seleksi yang diterima oleh suatu populasi serangga. Pada kondisi yang sama, suatu populasi hama yang menerima tekanan yang lebih keras akan berkembang menjadi populasi yang resisten dalam waktu yang lebih singkat dibandingkan populasi hama yang menerima tekanan seleksi yang lemah. Mekanisme resistensi suatu serangga terhadap insektisida dapat terjadi karena :

1. Peningkatan detoksifikasi insektisida menjadi tidak beracun oleh karena bekerjanya ensim-ensim tertentu seperti ensim dehidroklorinase (terhadap DDT), ensim mikrosomal oksidase (terhadap karbamat, OP, piretroid), glutation transferase (terhadap OP), hidrolase dan esterase (terhadap OP).

2. Penurunan kepekaan tempat sasaran insektisida pada tubuh serangga seperti asetilkolinesterase (terhadap OP dan karbamat), sistem syaraf seperti terhadap DDT dan piretroid.

3. Penurunan laju penetrasi insektisida melalui kulit atau integumentum seperti yang terjadi pada ketahanan terhadap kebanyakan insektisida.

Ketahanan serangga terhadap suatu jenis atau beberapa jenis insektisida disebabkan oleh lebih dari satu penyebab dan mekanisme ketahanan. Ada beberapa jenis serangga yang cepat membentuk populasi yang resisten tetapi ada yang lambat, ada juga jenis-jenis insektisida yang cepat menimbulkan reaksi ketahanan dari banyak jenis serangga. Mekanisme resistensi penyakit terhadap fungisida dan resistensi gulma terhadap herbisida pada prinsipnya tidak jauh berbeda dengan mekanisme resistensi hama terhadap insektisida (Georgiou dan Taylor, 1986).

Peningkatkan kasus resistensi terjadi sejalan dengan peningkatan jumlah penggunaan insektisida pada sekitar tahun 1960-1980 dan laju peningkatannya menurun setelah itu. Kerugian ekonomis yang disebabkan karena resistensi sangat besar dan kerugian tersebut tidak hanya ditanggung oleh perusahaan tetapi juga 
masyarakat petani baik karena peningkatan biaya, penurunan hasil maupun berkurangnya pilihan teknik pengendalian yang tersedia. Kerugian tersebut akan menjadi lebih besar dilihat dari sisi hilangnya individuindividu yang peka. Ulat kobis Plutella xylostella dan wereng $N$. lugens merupakan dua spesies serangga yang telah dilaporkan resisten (Trisyono, 2006).

\section{Residu Pestisida Pada Tanaman dan Lingkungan}

Residu pestisida yang ada di dalam tanah dapat terbawa oleh gerakan air tanah dan gerakan angin sehingga dapat masuk ke tubuh manusia melalui pernapasan ataupun air minum. Residu pestisida yang menempel atau masuk ke dalam jaringan tanaman atau hasil panen dapat masuk ke tubuh manusia karena termakan. Residu pestisida di dalam tanah bisa berakibat terbunuhnya organisme berguna di dalam tanah dan di atas permukaan tanah. Di Indonesia, residu pestisida yang terkandung di dalam sayuran: wortel, kentang, sawi, bawang merah, tomat dan kubis di beberapa sentra produksi sayuran dilaporkan telah melampaui batas maksimal 2 ppm yang merupakan batas minimum residu (BMR) yang telah ditetapkan Badan Standarisasi Nasional Th. 2008 (Amilia dkk, 2016). Gangguan kesehatan yang dapat terjadi pada manusia akibat pestisida kimia yaitu : mual, muntah, pusing, gatal pada kulit, infeksi saluran pernapasan, penglihatan menurun, kanker dan pada tingkat yang paling parah dapat menyebabkan kematian.

\section{Pengendalian OPT Ramah Lingkungan}

Penggunaan pestisida kimia sintetik secara berlebihan mempunyai banyak efek negatif. Dengan semakin kompleksnya permasalahan organisme penggangu tanaman dan efek negatif yang terjadi khususnya pada lingkungan dan gangguan kesehatan pada manusia maka upaya pengendalian organisme pengganggu tanaman secara ramah lingkungan menjadi suatu hal yang tidak boleh ditunda. Pemerintah sejak tahun 1986 (Inpres No.3 tahun 1986) telah mencanangkan sistem Pengendalian Hama Terpadu (PHT) sebagai suatu upaya pengendalian OPT secara ramah lingkungan untuk meningkatkan kuantitas dan kualitas hasil panen dengan mendasarkan pada aspek ekologi dan ekonomi (Jamal, 2020). PHT adalah suatu cara pendekatan atau cara berfikir tentang pengendalian hama (organisme pengganggu tanaman) memadukan beberapa metode yang kompatibel yang didasarkan pada pertimbangan ekologi dan efisiensi ekonomi dalam rangka pengelolaan agroekosistem yang berwawasan lingkungan yang terlanjutkan (Abadi, 2005 ; Untung, 2006).

Pengendalian OPT ramah lingkungan merupakan langkah pengendalian dengan menggunakan cara-cara yang dapat menekan serendah mungkin dampak negatif yang bisa timbul dan lebih mengarah pada penggunaan produk hayati (Prabaningrum $d k k$, 2015). Menurut Habazar $d k k$. (2010), program PHT lebih dinamis tidak hanya berwawasan ekologis tetapi juga mempertimbangkan usaha tani yang spesifik lokasi untuk meminimalkan perkembangan OPT. Oleh karenanya prinsip utama pengendalian OPT mengarah pada pengoptimalan sumber daya hayati di lingkungan agroekosistem (indigenus) dengan pertimbangan ekologis dan ekonomis.

PHT merupakan suatu sistem pengendalian yang menggunakan pendekatan ekologi, oleh karenanya pemahaman tentang biologi dan ekologi hama dan penyakit menjadi sangat penting. Ada empat prinsip dasar yang mendorong penerapan PHT secara nasional,terutama dalam rangka program pembangunan berkelanjutan yang berwawasan lingkungan. Menurut Prabaninrum dkk. (2015) beberapa prinsip dasar PHT pada tanaman sayuran adalah :

1. Budidaya tanaman sehat

2. Pemanfaatan musuh alami

3. Pengamatan rutin atau pemantauan

4. Petani sebagai ahli PHT

Oleh karenanya untuk keberhasilan penerapan PHT diperlukan komponen teknologi, sistem pemantauan yang tepat, dan petugas atau petani yang terampil dalam penerapan komponen teknologi PHT.

\section{Budidaya Tanaman Sehat}

Budidaya tanaman yang sehat akan menjadikan tanaman lebih kuat merupakan bagian penting dalam program pengendalian hama dan penyakit. Budidaya tanaman sehat akan berdampak tidak saja lingkungan yang sehat tetapi masyarakat petani juga menjadi sehat. Tanaman yang sehat lebih mampu bertahan terhadap serangan hama dan penyakit. Oleh karena itu setiap usaha dalam budidaya tanaman sehat dimulai dari tahap yang paling awal dari: tindakan pencegahan opt, penyiapan lahan/media semai, pemilihan varietas tahan, 
penyemaian, pemeliharaan tanaman, sampai dengan penanganan hasil panen memerlukan perhatian agar diperoleh pertanaman yang sehat, kuat dan produktif, serta hasil panen yang tinggi.

Pengolahan tanah merupakan salah satu metode pengendalian opt ramah lingkungan yaitu mencegah OPT dengan cara memodifikasi lingkungan fisikokimia tanah seperti suhu, kelembaban dan porousitas tanah menjadi lebih baik bagi tanaman. Dengan pengolahan tanah, struktur pembiakan jamur patogen tular tanah yang terbenam lebih dalam akan mati karena kekurangan oksigen, disamping itu pengolahan tanah juga akan menurunkan populasi hama di dalam tanah (Rahayu, 2013; Septariani dkk, 2020). Menurut Sulastri (2010), pemberian kapur dolomit pada tanah dapat meningkatkan $\mathrm{pH}$ tanah sehingga dapat mengurangi intensitas penyakit akar bengkak pada tanaman kubis-kubisan. Dilaporkan bahwa patogen penyebab akar bengkak akan sangat terdukung perkembangannya pada $\mathrm{pH}$ 5,7-6,2. Dengan meningkatkan $\mathrm{pH}$ tanah menjadi netral akan menghambat penyakit akar gada. Dalam pengolahan tanah sekaligus juga dilakukan penyiangan gulma karena gulma dapat berfungsi sebagai inang alternatif bagi opt. Gulma Portulaca oleraceae sering menjadi inang bakteri $R$. solanacearum penyebab penyakit layu (Lopez \& Biosca, 2004).

Beberapa metode yang ramah lingkungan untuk mengendalikan opt : rotasi tanaman, sistem tumpang sari, penggunaan varietas tahan, tanaman perangkap, penyiangan gulma dan penggunaan pestisida nabati. Rotasi tanaman bertujuan memutus siklus opt akibat tidak tersedia makanan bagi opt, namun perlu diperhatikan bahwa untuk opt yang mempunyai kisaran inang yang luas cara rotasi kurang memberikan hasil yang maksimal. Dilaporkan jamur patogen $R$. Solani mempunyai banyak kisaran inang yaitu : kacang tanah, kacang hijau, kedelai, buncis, kacang panjang (Semangun, 2008) dan juga dijumpai pada padi, jagung, tanaman hias dan beberapa sayuran yang lain (Soylu et al., 2005). Untuk mengendalikan penyakit jamur tersebut dengan cara rotasi kurang memuaskan. Dalam penggunaan varietas tahan yang pentng diperhatikan adalah informasi tentang karakter ketahanan yang dimiliki dan penyebarannya ke petani sebagai upaya preventif terhadap munculnta opt.

Menurut Mamahit dkk. (2018), penggunaan tanaman penghalang (jagung dan bunga taikoko) dapat digunakan untuk mengendalikan hama Thrips sp., sedangkan mulsa plastik bisa mengurangi hama Spodoptera $s p$., beberapa hama lain dan penyakit. Sulastri (2010) melaporkan adanya pengurangan tingkat keparahan penyakit akar gada pada tanaman kubis dengan memperlakukan tanaman caisin sebagai tanaman perangkap. Perlakuan yang diterapkan pada tanaman kubis sebagai berikut: A : Kontrol, B : Tanam caisin sebagai tanaman rotasi 38 hari sebelum tanam kubis disertai eradikasi manual, $\mathrm{C}$ : Tanam caisin sebagai tanaman rotasi 38 hari sebelum tanam kubis disertai eradikasi pengolahan tanah dan perendaman air 14 hari, D : Tanam caisin sebagai tanaman campuran diawal pertumbuhan kubis, E : Tanam caisin tumpang gilir 14 hari sebelum tanam kubis. Hasil penelitian menunjukkan bahwa perlakuan $\mathrm{C}$ memberikan keparahan penyakit akar gada kubis paling rendah (19\%) dibandingkan kontrol (45\%). Perlakuan C memberikan hasil krop : 39,2 t/ha sedangkan kontrol : 29,9 t/ha.

Pestisida nabati merupakan pestisida alternatif yang ramah lingkungan karena sifatnya mudah terurai. Pestisida ini memanfatkan senyawa sekunder sebagai bahan aktif bersumber dari tumbuhan (Regnault \& Roger, 2005). Dilaporkan banyak sekali spesies tanaman yang tumbuh di Indonesia seperti cengkih, mimba, serai wangi, jeringo, tembakau, pyrethrum, kunyit, dan jarak pagar dapat dimanfaatkan untuk mengendalikan hama dan penyakit tanaman. Untuk memperoleh manfaat yang optimal, penggunaan pestisida nabati sebaiknya ditujukan untuk mencegah terjadinya serangan, bukan untuk tindakan pengendalian (Wiratno $d k k$., 2013).

Di Indonesia pemanfatan pestisida nabati memiliki prospek yang baik, karena bahan bakunya melimpah di alam, proses pembuatannya tidak membutuhkan teknologi tinggi dan mudah terurai (bio-degradable) sehingga relatif aman. Sebagai contoh, insektisida nabati dari ekstrak bunga piretrum yang diaplikasikan untuk mengendalikan hama pada tanaman lada, sudah terdegradasi dalam waktu 24 jam (Wiratno $d k k$., 2008). Lebih lanjut Wiratno dkk. (2013) menyatakan insektisida nabati juga memiliki pengaruh cepat dalam menghambat nafsu makan serangga sehingga dapat menekan kerusakan tanaman. Keunggulan lainnya, pestisida nabati memiliki spektrum pengendalian yang luas dan dapat mengendalikan hama yang telah resisten terhadap insektisida sintetis. Karena tingkat toksisitasnya terhadap mamalia relatif rendah pestisida nabati aman bagi kehidupan.

Beberapa jenis gulma dilaporkan berpotensi untuk dimanfaatkan sebagai pestisida antara lain : Chromolaena odorata, Centrosema pubescens, Crotalaria macronata (sebagai nematisida), Ageratum conyzoides, Pachyrizus erosus (sebagai insektisida). Callistemon citrinus dengan bahan aktif metsotrione telah

Proceedings homepage: https://conferenceproceedings.ump.ac.id/index.php/pspfs/issue/view/9 
dimanfaatkan sebagai herbisida untuk gulma berdaun lebar dan rumput-rumputan pada tanaman jagung (Kurniadi, 2010).

\section{Pemanfaatan Musuh Alami untuk Pengendalian Secara Hayati}

Pengendalian hayati dengan memanfaatkan musuh alami yang potensial merupakan tulang punggung PHT. Dengan adanya musuh alami yang mampu menekan populasi opt, diharapkan di dalam agroekosistem terjadi keseimbangan populasi antara opt dengan musuh alaminya, sehingga populasi opt tidak melampaui ambang toleransi tanaman. Diantara musuh alami yang dapat dimanfaatkan untuk pengendalian hama dan penyakit tanaman secara hayati adalah cendawan entomopatogen Beauveria bassiana, Metarhizium sp dan Trichoderma sp. Cendawan B. bassiana merupakan salah satu spesies patogen pada serangga yang banyak dimanfaatkan untuk pengendalian serangga hama pada berbagai komoditas tanaman, karena cendawan ini mempunyai daya bunuh yang tinggi terhadap berbagai jenis serangga hama, mudah diperbanyak dan tidak bersifat toksik terhadap vertebrata (Wraight et al.2002). Beberapa agens hayati untuk mengendalikan patogen tular tanah yaitu:

Tabel 1. Ragam Agens Hayati dan Patogen Tular Tanah Sasaran Pengendalian

\begin{tabular}{|c|c|c|c|}
\hline Agens Hayati & Patogen Tular Tanah & Inang & Pustaka \\
\hline \multirow{3}{*}{$\begin{array}{l}\text { Pseudomonas sp. } \\
\text { P.fluorescens }\end{array}$} & S. rolfsii, Fusarium & Kedelai, & Ganesan et al., (2003\&2004) \\
\hline & R. soloni & Kacang tanah & Doan dan Nguyen (2006), \\
\hline & R. solanacearum & & Rahayu (2006 dam 2008) \\
\hline \multirow{3}{*}{$\begin{array}{l}\text { Bacillus spp. } \\
\text { Bacillus subtilis } \\
\text { AU195 }\end{array}$} & R. solanacearum & Kacang tanah & Doan dan Nguyen (2006) \\
\hline & A. flavus & & Moyne et al., (2001) \\
\hline & & & Tamehiro et al., (2002) \\
\hline \multirow{5}{*}{$\begin{array}{l}\text { Trichoderma spp. } \\
\text { T. harzianum } \\
\text { T. atroviride } \\
\text { T. viride }\end{array}$} & R. solani, A. flavus & Kacang tanah, & Kajal dan Chitreswar (2000), \\
\hline & Fusarium, Pythium & Aneka kacang & Iglis dan Kawchuck (2002), \\
\hline & & & Ganesan dan Sekar (2004) \\
\hline & & & Reithner et al., (2005) \\
\hline & & & Rajeswari dan Kannabiran (2011) \\
\hline $\begin{array}{l}\text { Gliocladium } \\
\text { roseum }\end{array}$ & $\begin{array}{l}R . \text { soloni, } S . \text { rolfsii } \\
\text { A. niger, Fusarium } \\
\text { colletotricum }\end{array}$ & Kedelai & Hardaningsih (1997) \\
\hline
\end{tabular}

Sumber: Rahayu (2013)

Menurut Septariani $d k k .(2020)$, di beberapa tempat petani sudah banyak yang menerapkan tanaman refugia sebagai penyedia tempat perlindungan dan sumber pakan atau sumber nektar bagi musuh alami hama seperti predator dan parasitoid. Tanaman refugia ditujukan sebagai upaya konservasi musuh alami sehingga mekanisme pengendalian oleh agens hayati akan berjalan secara alamiah. Di Alahan Panjang, Kab. Solok, Sumatera Barat aplikasi Beauveria bassiana dan Trichoderma pada pertanaman bawang merah dapat menurunkan persentase tanaman yang terserang Liriomyza sp dan S. exigua.

Tabel 2. Tingkat Serangan Hama Liriomyza sp. dan Spodoptera exigua pada Tanaman Bawang Merah di

\begin{tabular}{lcc} 
& \multicolumn{2}{c}{ Alahan Panjang } \\
\cline { 2 - 3 } Perlakuan & \multicolumn{2}{c}{ \% Tanaman Terserang } \\
\hline Beauveria bassiana & Liriomyza sp. & S. exigua \\
Trichoderma & 30.00 & 6.67 \\
Ekstrak limbah bawang merah & 37.41 & 8.52 \\
Kontrol & 38.15 & 12.22 \\
\hline
\end{tabular}

Sumber : Trizelia dan Winarto (2017)

\section{Pengamatan Rutin atau Pemantauan}

Agroekosistem bersifat dinamis, karena banyak faktor di dalamnya yang saling mempengaruhi satu sama lain. Untuk dapat mengikuti perkembangan populasi OPT dan musuh alaminya serta untuk mengetahui kondisi tanaman, harus dilakukan pengamatan secara rutin. Informasi yang diperoleh digunakan sebagai dasar tindakan yang akan dilakukan. Dikarenakan jumlah petugas pengamat atau penyuluh di daerah sangat terbatas maka yang paling baik kegiatan pengamatan dilakukan sendiri oleh petani pemilik maupun penggarap. Petani sendiri 
yang melakukan kegiatan pemantauan, pengambilan keputusan dan tindakan pengendalian. Dengan demikian petani tidak lagi tergantung pada petugas, pemerintah.

Petani dapat melakukan pengamatan secara perseorangan atau individu, namun yang paling baik secara berkelompok atau merupakan kegiatan kelompok tani. Agar petani dapat melakukan kegiatan pemantauan ekosistem dengan baik, perlu adanya pembekalan pengetahuan dan keterampilan yang memadai antara lain dengan mengikuti pelatihan khusus yang dilaksanakan secara intensif dan terjadwal. Dengan demikian tujuan pelaksanaan kegiatan pengamatan oleh para petugas hanya terbatas pada penyusunan laporan bagi pemerintah daerah maupun pemerintah pusat tetapi tidak untuk pengambilan keputusan untuk lahan petani dalam menerapkan PHT (Untung, 2006).

\section{Petani Sebagai Ahli PHT}

Penerapan PHT dan pengendalian opt secara ramah lingkungan harus disesuaikan dengan keadaan ekosistem setempat. Rekomendasi PHT dan pengendalian opt ramah lingkungan hendaknya dikembangkan oleh petani sendiri. Agar petani mampu menerapkan metode pengendalian secara tepat, diperlukan usaha pemasyarakatan melalui pelatihan baik secara formal maupun informal. Di Desa Purwaharja, Banjar, Jawa Barat sebanyak $77,1 \%$ petani menyatakan bahwa adanya penyuluh berperan besar dalam pengendalian OPT khususnya pengaplikasian enam tepat pestisida sesuai konsepsi PHT (A'yunin dkk., 2020). Hubungan antara pemantauan, pengambilan keputusan dan tindakan dalam pelaksanaan PHT bisa digambarkan (Prabaningrum dkk., 2015):

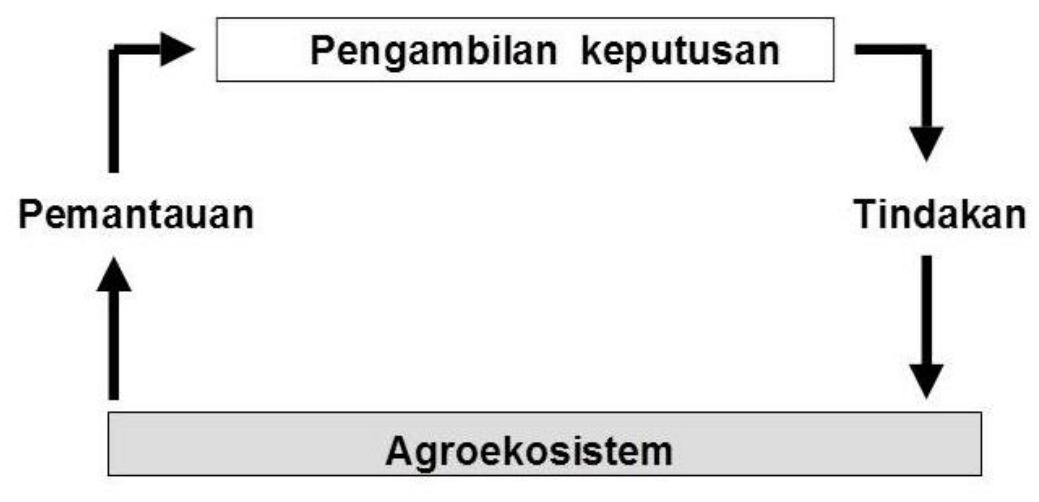

\section{Hubungan antara pemantauan, pengambilan keputusan, dan tindakan dalam pelaksanaan PHT}

\section{Penggunaan Pestisida Kimia Sintetik Secara Tepat}

Penggunaan pestisida kimia sintetik dalam konsep PHT yang ramah lingkungan diaplikasikan ketika cara-cara selain kimiawi dipandang tidak mampu mengatasi permasalahan opt. Penggunaan pestisida harus memenuhi enam tepat sesuai konsepsi PHT (Puslitbanghor Kementan RI, 2002):

1. Tepat Sasaran: sesuai dengan jenis opt yang menyerang

2. Tepat Mutu: bermutu baik yaitu terdaftar dan diijinkan oleh Komisi Pestisida.

Nomor ijin, Peruntukan, Kode Produksi, Tanggal produksi, Tanggal kedaluwarsa, Nama dan alamat pembuat

3. Tepat jenis : sesuai dengan suatu jenis opt pada suatu jenis tanaman

4. Tepat waktu penggunaan : saat opt mencapai ambang pengendalian, waktu pk.16.00-17.00, suhu $<30^{\circ} \mathrm{C}$, kelembaban udara 50-80\%

5. Tepat dosis atau konsentrasi formulasi : sesuai dengan rekomendasi anjuran pada label atau kemasan

6. Tepat cara penggunaan : disemprotkan, perlakuan benih, dll

\section{Indikator Keberhasilan Pengendalian Hama yang Ramah Lingkungan}

Indikator keberhasilan pengendalian hama yang ramah lingkungan dapat dilihat dari beberapa parameter:

a. Keseimbangan ekosistem tetap terjaga

b. Biodiversity tetap lestari

c. Populasi musuh alami meningkat 
d. Residu pestisida diminalisasi

e. Lingkungan terjaga keberlanjutannnya

f. Biaya produksi menurun

h. Kesehatan manusia terjamin keamanannya

\section{PENUTUP}

Untuk dapat memproduksi komoditas pertanian lebih baik secara kuantitas dan kualitas, berkesinambungan dan terjaga kelestarian lingkungan hidup, salah satu faktor penting sebagai pendukung adalah tindakan pengendalian organisme pengganggu tanaman ramah lingkungan. Pengendalian hama terpadu (PHT) sebagai suatu sistem pengendalian opt ramah lingkungan hendaknya dilakukan dengan mendasarkan pada prinsip:

Budidaya tanaman sehat, Pemanfaatan musuh alami, Pengamatan rutin atau pemantauan dan Petani berperan sebagai ahli PHT. Pengendalian opt ramah lingkungan diharapkan bisa mempercepat tercapainya tujuan Pertanian Berkelanjutan yaitu: a. Meningkatkan dan memperluas penganekaragaman hasil pertanian, guna memenuhi kebutuhan pangan, sandang, papan, kesehatan, industri dalam negeri, dan memperbesar ekspor; b. Meningkatkan pendapatan dan taraf hidup Petani; dan c. Mendorong perluasan dan pemerataan kesempatan berusaha dan kesempatan kerja.

\section{DAFTAR PUSTAKA}

Abadi, A. L. 2005. Permasalahan Dalam Penerapan Sistem Pengendalian Hama Terpadu Untuk Pengelolaan Penyakit Tumbuhan Di Indonesia. Pidato Pengukuhan Jabatan Guru Besar dalam Ilmu Penyakit Tumbuhan pada Fakultas Pertanian Universitas Brawijaya, Malang.

Amilia, E., Joy, B., Sunardi. 2016. Residu Pestisida Pada Tanaman Hortikultura (Studi Kasus Di Desa Cihanjuan Rahayu, Kec. Parongpong, Kab. Bandung Barat). Jurnal Agrikultura 27 (1) : 23-29.

A’yunin, N.Q., Achdiyat, Tri R.S. 2020. Preferensi Anggota Kelompok Tani Terhadap Penerapan Prinsip Enam Tepat (6T) Dalam Aplikasi Pestisida. Jurnal Inovasi Penelitian. Vol.1 No.3., Bogor : 253-264.

Badan Standarisasi Nasional. 2008. Batas Maksimum Residu Pestisida pada Hasil Pertanian. SNI 7313:2008.

Georgiou G.P. \& C.E. Taylor. 1986. Factors Influencing The Evolution of Resistance, pp.157-169, In Committee on Strategies for The Management of Pesticide Resistant Pest Populations (ed.). Pesticide Resistance : Strategies and Tactics for Management. National Academy Press, Washington, D.C.

Habazar, T., Trizelia., Yulmira, Y. 2010. Bioteknologi Perlindungan Tanaman. Andalas University Press., Padang : 19-20.

Hasyim, A., Setiawati, W., Lukman, L. 2015. Inovasi Teknologi Pengendalian OPT Ramah Lingkungan Pada Cabai : Upaya Alternatif Menuju Ekosistem Harmonis. Jurnal Pengembangan Inovasi Pertanian. Vol.8 No1 : 1-10.

Jamal, E. 2020. Diskusi Pestisida di Indonesia : Industri, Rantai Pasok dan Penggunaan. Pusat Perlindungan Varietas Tanaman dan Perijinan Tanaman. Kementerian Pertanian RI, Jakarta.

Kurniadie, D. 2010. Weed Control Without Chemical Subtances. Journal of Tropical Weeds and Invasive Plants. Weed Science Society of Indonesia. Vol (1) : 2.

Lopez, M.M. and Biosca, E.G. 2004. Potato Bacterial Wilt Management : New Prospects for An Old Problem. In : Allen C., Prior P., and Hayward AC. (eds). Bacterial Wilt Diseases and The Ralstonia species Complex. APS Press, St. Paul, Minnesota, USA. Pp.205-224.

Mamahit, J.M.E., Manueke, J., Montong, V.B. 2018. Inovasi Teknik Pengendalian Hama yang Ramah Lingkungan Pada Tanaman Krisan. Jurnal LPPM Bidang Sains dan Teknologi. Unsrat. Manado. Vol.5 No. 2 : 47-56.

Prabaningrum L, Moekasan, T.K., Adiyoga, W., Gunadi, N. 2015. Empat Prinsip Dasar Dalam Penerapan Pengendalian Hama Terpadu (PHT). Balitsa. Balitbangtan. Kementan RI. https://balitsa.litbang.pertanian.go.id/ind/ index.php/berita-terbaru/378-empat-prinsip-dasar-dalampenerapan-pengendalian-hama-terpadu-pht.html.

Rahayu, R. 2013. Ragam Penyakit Tular Tanah Pada Tanaman Aneka Kacang dan Strategi Pengendalian Non Kimiawi. Prosiding Seminar Hasil Penelitian Tanaman Aneka Kacang dan Umbi, Malang : 816-830.

Proceedings homepage: https://conferenceproceedings.ump.ac.id/index.php/pspfs/issue/view/9 
Ratna, Y., Trisyono,Y.A., Untung, K., Indradewa, D. 2009. Resurjensi Serangga Hama Karena Perubahan Fisiologi Tanaman dan Serangga Sasaran Setelah Aplikasi Insektisida. Jurnal Perlindungan Tanaman Indonesia. Vol.15 No.2 : 55-64.

Regnault \& Roger, C. 2005. New insecticides of plant origin for the third millenium? In B.J.R. Regnault-Roger, C. Philogene, and C. Vincent (Eds). Biopesticides of Plant Origin. Lavoisier Publishing Inc. pp. 17-35.

Septariani, D.N., Suminah, Liana, I.M., Cahyono, S.A. 2020. Pengendalian OPT Ramah Lingkungan Pada Brokoli Mendukung Good Agricultural Practices : Review. Prosiding Seminar Nasional dalam Rangka Dies Natalis ke 44 UNS Th. 2020 “Strategi Ketahanan Pangan Masa New Normal Covid-19”, Surakarta.

Singkoh, M.F.O. dan Katili, D.Y. 2019. Bahaya Pestisida Sintetik (Sosialisasi dan Pelatihan Bagi Wanita Kaum Ibu Desa Koka, Kec. Tombulu, Kab. Minahasa. Jurnal Perempuan dan Anak Indonesia. Vol.1 No.1 : 512.

Sulastri, E. 2010. Penurunan Intensitas Akar Gada dan Peningkatan Hasil Kubis dengan Penanaman Caisin Sebagai Tanaman Perangkap Patogen. http://eprints.uns. ac.id/5856/1/158632408201001031.pdf

Trisyono, Y.A., 2006. Resistensi Serangga Terhadap Insektisida. Laboratorium Toksikologi Pestisida FP UGM, Yogyakarta

Trizelia dan Winarto. 2017. IbM Penerapan Teknologi Pengendalian OPT Ramah Lingkungan Untuk Meningkatkan Produktivitas Sayuran dan Mendukung Pertanian Organik Di Alahan Panjang. Jurnal Warta Pengabdian Andalas. Vol.24 No.4, Padang : 16-37.

Undang-Undang RI No. 22 Tahun 2019 tentang Sistem Budi Daya Pertanian Berkelanjutan.

Untung, K. 2006. Pengantar Pengelolaan Hama Terpadu (Edisi kedua). Gadjah Mada University Press, Yogyakarta.

Wiratno, Siswanto, Trisawa, I.M.. 2013. Perkembangan Penelitian, Formulasi, dan Pemanfatan Pestisida Nabati. J. Litbang Pertanian. Vol.32 No.4 : 150-155.

, D. Taniwiryono, I.M.C.M. Rietjens, and A.J. Murk. 2008. Bioactivity of Plant Extracts to T.castaneum. Effectiveness and Safety of Botanical Pesticides Applied in Black Pepper. Wageningen University. Wageningen p. 26.

Wraight SP, Ramos MB. 2002. Application parameters affecting field efficacy of Beauveria bassiana foliar treatments against Colorado potato beetle Leptinotarsa decemlineata. Biol Contr 23:164-178. 